\title{
Examination of the liver in personnel working with liquid rocket propellant
}

\author{
PALLE PETERSEN, ERIK BREDAHL, OVE LAURITSEN, \\ and THOMAS LAURSEN \\ Medical Department TA and Department of Clinical Chemistry, Rigshospitalet, \\ Copenhagen and the Danish Air Force
}

\begin{abstract}
Petersen, P., Bredahl, E., Lauritsen, O., and Laursen, T. (1970). Brit. J. industr. Med., 27, 141-146. Examination of the liver in personnel working with liquid rocket propellants. Personnel working with liquid rocket propellants were subjected to routine health examinations, including liver function tests, as the propellant, unsymmetrical dimethylhydrazine (UDMH) is potentially toxic to the liver. In 46 persons the concentrations of serum alanine aminotransferase (SGPT) were raised.

Liver biopsy was performed in 26 of these men; 6 specimens were pathological (fatty degeneration), 5 were uncertain, and 15 were normal. All 6 pathological biopsies were from patients with a raised SGPT at the time of biopsy. Of the 15 persons with a normal liver biopsy, 14 had a normal SGPT, while one (who was an alcoholic) had a raised SGPT. The connection between SGPT and histology of the liver, as well as the possible causal relation between the pathological findings and exposure to UDMH, is discussed.
\end{abstract}

Modern rocket propellants present special problems regarding the protection of personnel working with them, as many are highly toxic chemical compounds. These include unsymmetrical dimethylhydrazine (UDMH) which is employed by the Danish Missile Force.

UDMH is a high explosive, colourless liquid with an ammonia-like, fishy smell. The vapour is inflammable in air and is spontaneously ignited when in contact with oxidizing agents. The threshold limit value is given as 0.5 part per million (Committee on Threshold Limits, 1959). The lowest concentration perceivable by smell is 6 to 14 parts per million (Department of the Army Technical Bulletin, 1957; Office of the Assistant Secretary of Defense, Research, and Engineering, 1958; Stumpe, 1958).

The acute, toxic effects comprise local irritation of membranes and effects of absorption with symptoms referable to the central nervous system (Office of the Assistant Secretary of Defense, Research and Engineering, 1958; Comstock, Lawson, Greene, and Oberst, 1954; Dill and Jacob- son, 1960; Jacobson, Clem, Wheelwright, Rinehart, and Mayes, 1955).

The chronic, toxic effects of UDMH are less well known. Hydrazine may cause liver injury. As UDMH is closely related to hydrazine with respect to both chemical structure and toxicity (Comstock et al., 1954; Dill and Jacobson, 1960; Jacobson et al., 1955; Krop, 1954) it seemed worth while to investigate its possible liver-damaging effects. Animals exposed to UDMH for shorter periods of time showed no evidence of liver damage (Jacobson et al., 1955). Five men working at a chemical laboratory with UDMH observing the prescribed cautionary measures, and six men working in open air decanting UDMH, were all found (Shook and Cowart, 1957) to suffer from hepato-cellular degeneration as evidenced by a positive cephalin-cholesterol flocculation test $(1++++, 2+++, 8++$ or +$)$; liver biopsies were not performed. Certain hydrazine derivatives used in medicine (isoniazid and isocarboxazid) are known to be potentially toxic to the liver when 
administered for a prolonged period of time (Pare and Sandler, 1959; Sherlock, 1963).

Filling with the propellant is regulated by carefully established and comprehensive security regulations designed to prevent the substance, in liquid or gaseous form, escaping from the closed system used. The men directly employed with the filling are dressed in protective suits with hoods and masks, gloves, boots, and respirators with atmospheric air in a closed system. The filling is supervised by an officer who ensures that the regulations are kept. He is not dressed in a protective suit but stays upwind outside the safety limit of $25 \mathrm{~m}$.

In the Danish Air Force about 350 to 400 persons are occupied with liquid rocket propellants. Routine health examinations including certain laboratory tests are performed three or four times a year. The laboratory tests comprise determination of urinary urobilin, urobilinogen, protein, and glucose, examination of the blood including haemoglobin determination, leucocyte count, and differential leucocyte count. The activity of serum alanine aminotransferase (SGPT) is also determined. The SGPT is determined by a fluorimetric method (Laursen and Hansen, 1958) and expressed as units ( $\mu \mathrm{mol} / \mathrm{hour}$ ) per $\mathrm{ml}$. A $95 \%$ normal range of 0 to 1.8 units $/ \mathrm{ml}$ was obtained from 94 blood donors, and an identical normal range was found for hospital personnel of different ages ( 73 men and 99 women 20 to 60 years old).

In the period from March 1961 to January 1964, the SGPT was found to be raised at one or more determinations in 47 out of 1193 persons examined (i.e., in $4 \%$ ). As this was taken to reflect liver cell damage (Laursen and Svendsen, 1959) some liver biopsies were performed. Some of the persons had been demobilized, three had infectious mononucleosis as a reasonable explanation of the raised SGPT, and two refused to go to hospital. The remaining 27 men were admitted to hospital, and 26 of them had a liver biopsy (one refused liver biopsy). The other examinations performed on the patients admitted to hospital revealed normal conditions: haemoglobin concentration, erythrocyte sedimentation rate, total and differential leucocyte count, platelet count, Wassermann test, serum concentrations of alkaline phosphatase, lactate dehydrogenase and creatinine, thymol turbidity test, bromsulphalein test, Paul-Bunnell test, electrocardiogram, and chest $\mathrm{x}$-ray. (In one patient a slightly increased serum concentration of bilirubin, 3.0 to $5.0 \mathrm{mg} / 100 \mathrm{ml}$, was found.)

The liver biopsies were performed in the morning using the Menghini method with local anaesthesia. The histological findings were as follows:

Slight to rather pronounced degrees of fatty liver

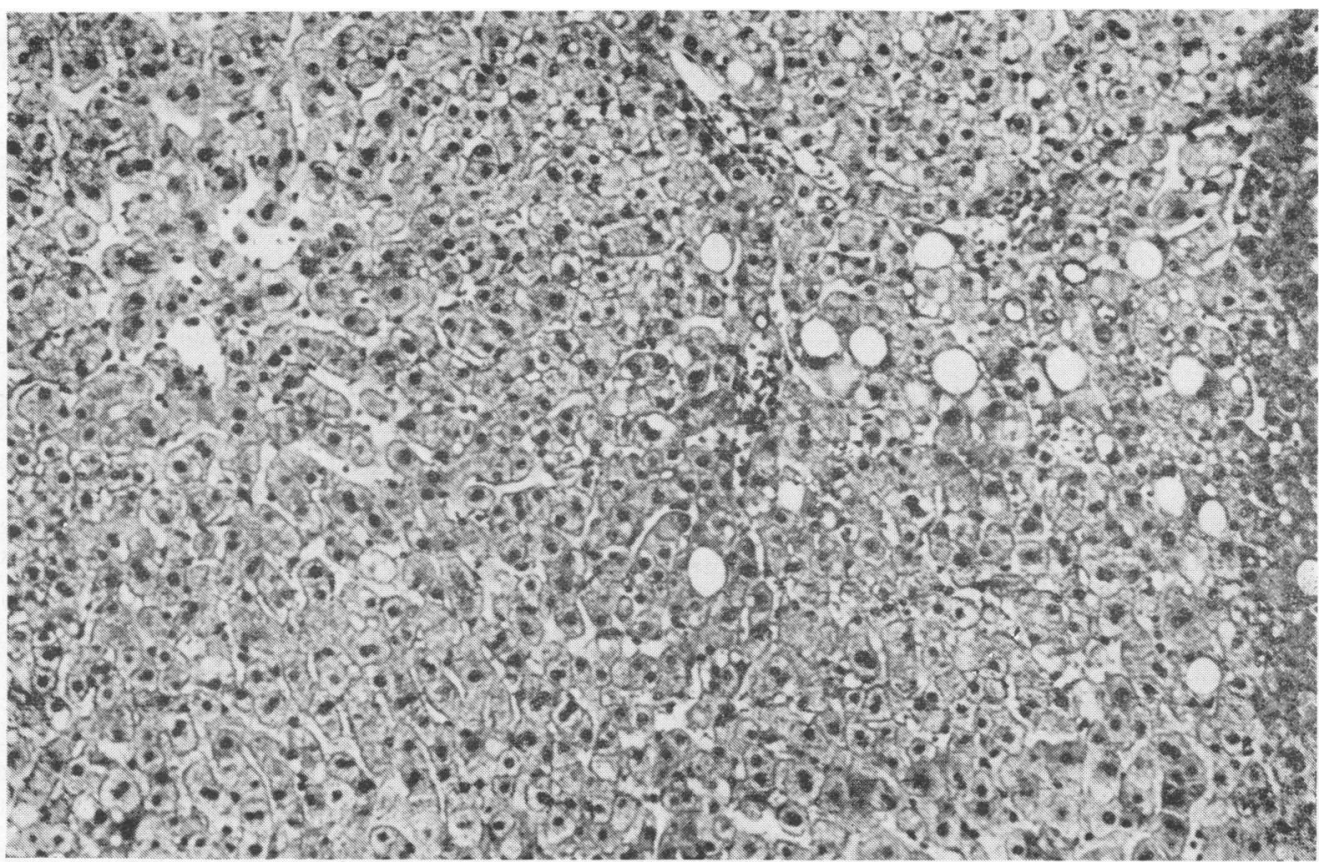

FIG. 1. Liver biopsy shows slight fatty degeneration. Van-Gieson Hanssen. $\times 100$. 
were found in six cases. No increase in the amount of connective tissue, cellular infiltration, cholestasis or signs of inflammation were observed.

In five cases the histological appearance could not, with certainty, be characterized as pathological. In four cases a few cells showed fatty degeneration, and in one case a slightly increased infiltration with lymphocytes was observed in the portal areas.

In 15 cases no histological changes were seen.

Figures 1 and 2 show examples of fatty liver to slight or rather pronounced degrees, respectively.

Tables 1, 2 and 3 relate the biopsy findings to the values of SGPT at the time of biopsy. From Table 1 it is seen that the SGPT was slightly raised at the time of biopsy in all the six persons whose biopsy revealed a fatty liver. From Table 2 it is seen that the SGPT varied between $1 \cdot 1$ and $2 \cdot 1$ units $/ \mathrm{ml}$ in the persons whose biopsy did not show certain histological changes. SGPT was normal in 14 of the 15 persons with normal biopsies (Table 3).

Figures 3, 4 and 5 show the course of SGPT in the three groups mentioned.

\section{Discussion}

A comparison of the findings of the liver biopsies with the values of SGPT shows a good correlation between the histopathological findings and the values of SGPT at the time of biopsy, the fatty liver in nearly all cases being accompanied by a slight increase in SGPT.

An increase in the serum concentration of transaminases is usually interpreted as reflecting liver cell damage (Stumpe, 1958; Pare and Sandler, 1959; Laursen and Svendsen, 1959; Kallai, Hahn, Röder, and Zupanić, 1964; Reés and Sinha, 1960; Vido and Tomik, 1963). In patients with acute hepatitis an increased concentration of SGPT is the earliest sign of liver parenchymal damage (Laursen and Svendsen, 1959).

In our biopsies no signs of cellular necrosis were observed, only fatty degeneration which was accompanied by an increased concentration of SGPT. Although there was not a close association between the extent of the fatty degeneration and the increase in SGPT, the association found between the biopsy findings and the SGPT values suggests that SGPT is a sensitive indicator of liver cell damage.

The question now arises whether the changes in SGPT and in liver histology should be attributed to work with UDMH. This question cannot be settled with certainty, but we think that the possibility cannot be ruled out. It has not been possible, by investigating the history of the patients, to find an obvious association between liver damage and exposure to UDMH. However, although all personnel employed with the propellant were acquainted with the smell of UDMH, the concentrations at which it

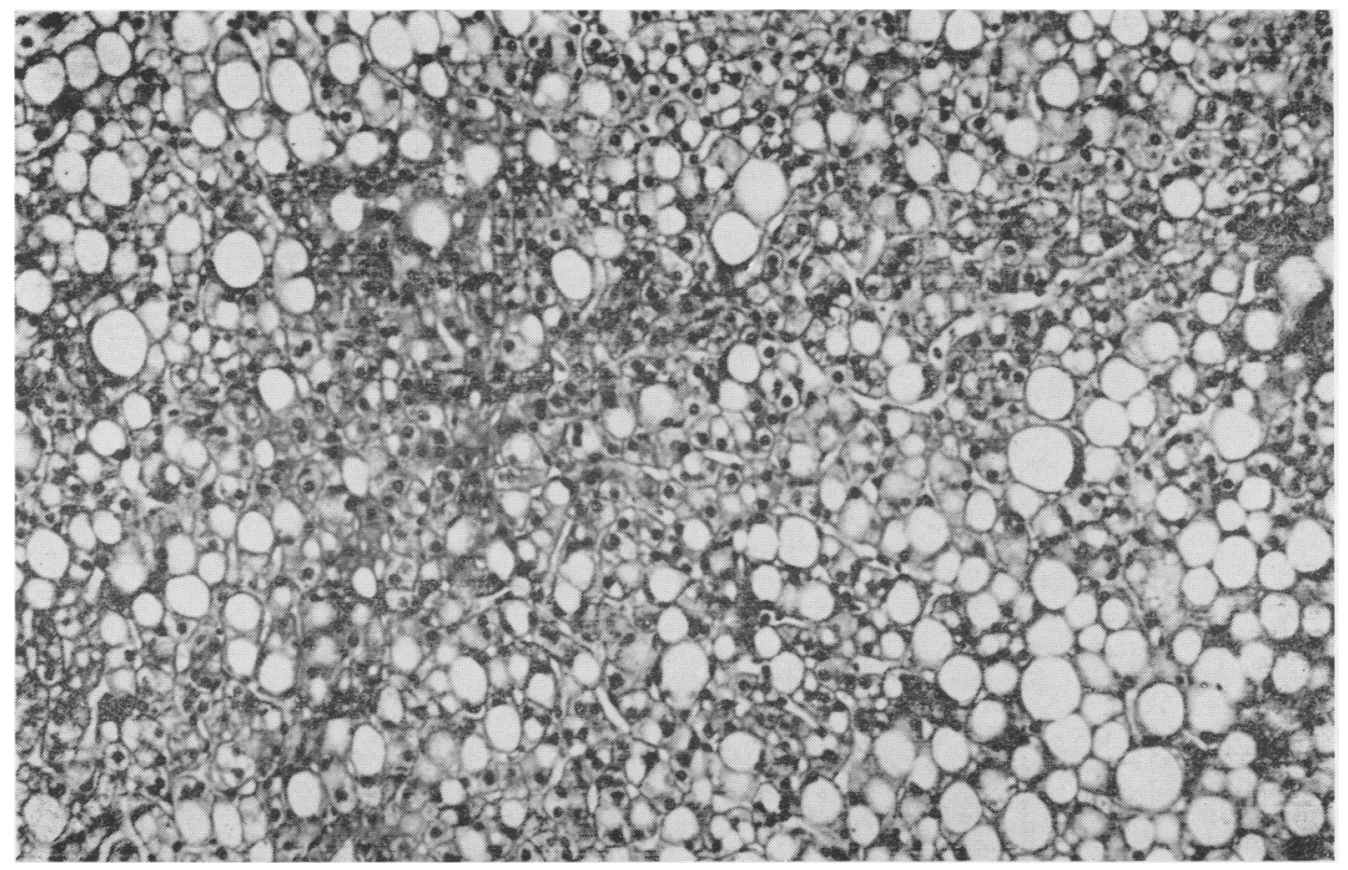

FIG. 2. Liver biopsy shows pronounced fatty degeneration. Van-Gieson Hanssen. $\times 100$. 
TABLE 1

Correlation between Biopsy findings (Fatty Liver), Value of SGPT at Time of BIOPSY, AND EXPOSURE TO UDMH

\begin{tabular}{|c|c|c|c|c|}
\hline Patient & $\begin{array}{l}\text { Age } \\
(y r)\end{array}$ & $\begin{array}{l}\text { SGPT } \\
(u / m l)\end{array}$ & Biopsy findings & Exposure \\
\hline 218 & 30 & 1.9 & $\begin{array}{l}50-75 \% \text { of liver cells changed to fat } \\
\text { cells }\end{array}$ & $\begin{array}{l}\text { At a distance from filling-up area for several } \\
\text { years + protection }\end{array}$ \\
\hline 526 & 19 & $2 \cdot 1$ & Slight diffuse fatty degeneration & $\begin{array}{l}20-30 \mathrm{~m} \text { from filling-up area } 2 \text { years }+ \\
\text { protection }\end{array}$ \\
\hline 1003 & 21 & $2 \cdot 3$ & $\begin{array}{l}\text { A good deal of diffuse fatty } \\
\text { infiltration }\end{array}$ & Filling-up area 1 year before + protection \\
\hline 212 & 25 & $2 \cdot 6$ & Rather strongly fatty degeneration & $\begin{array}{l}\text { Filling-up area } 4 \text { years, } 1 \text { year }+3 \text { years } \\
+ \text { protection }\end{array}$ \\
\hline $\begin{array}{l}711 \\
508\end{array}$ & $\begin{array}{l}38 \\
21\end{array}$ & $\begin{array}{l}2 \cdot 7 \\
2 \cdot 7\end{array}$ & $\begin{array}{l}\text { Slight to moderate fatty degeneration } \\
\text { Very slight fatty degeneration }\end{array}$ & $\begin{array}{l}\text { Filling-up area } 4 \text { years }+ \text { protection } \\
200 \mathrm{~m} \text { from firing area } 4 \text { months }+ \text { protection }\end{array}$ \\
\hline
\end{tabular}

SGPT Mean \pm SD $=2 \cdot 38 \pm 0 \cdot 34$

TABLE 2

Correlation between Biopsy findings (No Certain Histological Changes), Value of SGPT AT TIME OF BIOPSY, AND EXPOSURE TO UDMH

\begin{tabular}{|c|c|c|c|c|}
\hline Patient & $\begin{array}{l}\text { Age } \\
(y r)\end{array}$ & $\begin{array}{l}\text { SGPT } \\
(u / m l)\end{array}$ & Biopsy findings & Exposure \\
\hline 829 & 20 & $1 \cdot 1$ & $\begin{array}{l}\text { Some fatty vacuoles around central } \\
\text { vein }\end{array}$ & Firing area 2 months + protection \\
\hline 738 & 33 & $1 \cdot 2$ & $\begin{array}{l}\text { A few liver cells with fatty degener- } \\
\text { ation }\end{array}$ & $\begin{array}{l}\text { At a distance from filling-up area } 5 \text { years }+ \\
\text { protection }\end{array}$ \\
\hline 498 & 22 & $1 \cdot 6$ & $\begin{array}{l}\text { Slight periportal lymphocyte infil- } \\
\text { tration }\end{array}$ & Workshop 5 months + protection \\
\hline $\begin{array}{l}830 \\
591\end{array}$ & $\begin{array}{l}24 \\
21\end{array}$ & $\begin{array}{l}1 \cdot 6 \\
2 \cdot 1\end{array}$ & $\begin{array}{l}\text { In places fatty vacuoles in liver cells } \\
\text { A few liver cells with fatty degener- } \\
\text { ation }\end{array}$ & $\begin{array}{l}\text { Firing area } 4 \text { months }+ \text { protection } \\
\text { Filling-up area and workshop } 2 \text { years }+ \\
\text { protection }\end{array}$ \\
\hline
\end{tabular}

SGPT Mean $\pm \mathrm{SD}=1.52 \pm 0.40$

TABLE 3

Correlation between Biopsy Findings (Normal in all Cases), Value of SGPT at TIME OF BIOPSY, AND EXPOSURE TO UDMH

\begin{tabular}{|c|c|c|c|}
\hline Patient & $\begin{array}{l}\text { Age } \\
(y r)\end{array}$ & $\begin{array}{l}\text { SGPT } \\
(u / m l)\end{array}$ & Exposure \\
\hline $\begin{array}{r}492 \\
602 \\
560 \\
681 \\
561 \\
629 \\
1012 \\
435 \\
491 \\
628 \\
497 \\
658 \\
592 \\
525 \\
1026\end{array}$ & $\begin{array}{l}21 \\
24 \\
19 \\
29 \\
19 \\
25 \\
17 \\
22 \\
31 \\
26 \\
19 \\
21 \\
26 \\
22 \\
21\end{array}$ & $\begin{array}{l}0.5 \\
0.5 \\
0.7 \\
0.7 \\
0.8 \\
0.8 \\
0.8 \\
0.9 \\
0.9 \\
1.0 \\
1.0 \\
1.1 \\
1.2 \\
1.3 \\
2.3\end{array}$ & $\begin{array}{l}\text { Workshop } 4 \text { months }+ \text { protection } \\
\text { Filling-up area } 5 \text { years + protection } \\
\text { Filling-up area } 6 \text { months }+ \text { protection } \\
\text { At a distance from filling-up and firing area for several years }+ \text { protection } \\
\text { Firing area } 1 \frac{1}{2} \text { years + protection } \\
\text { Firing area } 4 \text { years }+ \text { protection } \\
\text { Transport for a few months }+ \text { protection } \\
\text { Filling-up area } 3 \text { years }+ \text { protection } \\
\text { Workshop and filling-up area } 5 \text { years }+ \text { protection } \\
\text { At a distance from filling-up area } 2 \frac{1}{2} \text { years }+ \text { protection } \\
\text { At a distance from filling-up area } 2 \text { years }+ \text { protection and filling-up }+ \text { protection } \\
\text { Filling-up area } 1 \text { year + protection } \\
\text { Firing area } 5 \text { years }+ \text { protection } \\
\text { Workshop } 6 \text { months }+ \text { protection } \\
\text { From the same military department }+ \text { exposure }\end{array}$ \\
\hline
\end{tabular}

SGPT Mean \pm SD $=0.97 \pm 0.43$ 


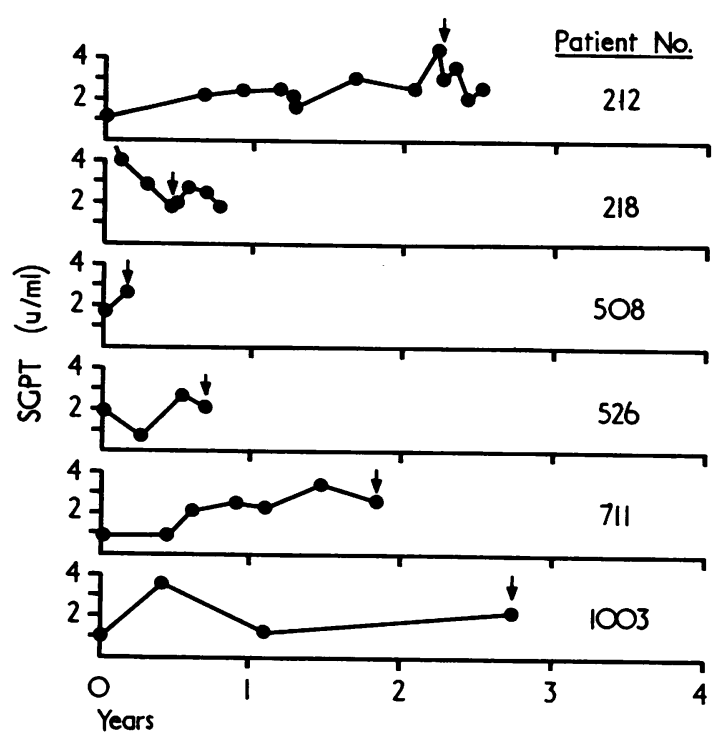

FIG. 3. The course of SGPT in the group whose liver biopsy showed a fatty liver. The arrow indicates the time of liver biopsy.

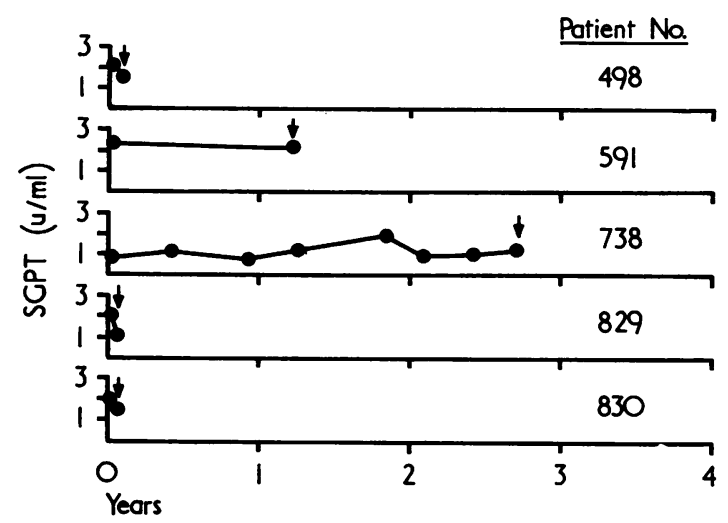

FIG. 4. The course of SGPT in the group whose liver biopsy showed uncertain histological changes. The arrow indicates the time of liver biopsy.

may first be detected by smell are higher than the threshold limit. Furthermore, as previously stated, there is some evidence that UDMH is toxic to the liver on prolonged exposure.

Carbon tetrachloride as a causative agent can be excluded as all patients denied exposure to this material. A third possibility is abuse of alcohol. On thorough questioning about their drinking habits, 25 of the 26 patients on whom liver biopsy was performed denied abuse of alcohol. One declared a moderate abuse of alcohol; he did not have a fatty liver. A deficient diet is considered to be an important pathogenic factor in the alcoholic fatty liver (Isselbacher and Greenberger, 1964). This factor may be excluded, as the personnel received an adequate diet.

Infectious mononucleosis may also be ruled out. All 26 patients were questioned about throat infections, the Paul-Bunnell test was negative, and the blood smear did not reveal McKinley cells. Furthermore, the above-mentioned histological findings in the liver are not typical of infectious mononucleosis, the usual finding in this condition being an infiltration of the liver with mononuclear cells (Bennike, 1960).

A progressive return to normal of the pathological changes, after the patients have been removed from UDMH, would argue strongly in favour of UDMH being the causative agent. We have not yet had an opportunity to repeat the biopsies.

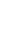

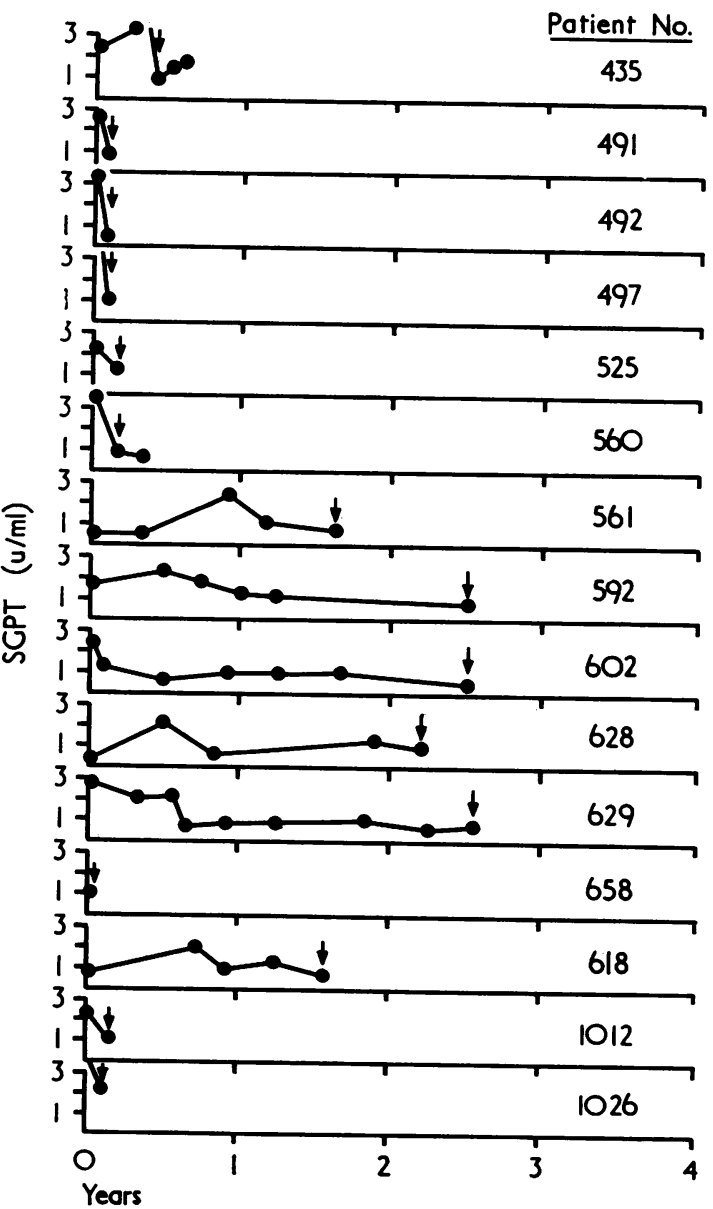

FIG. 5. The course of SGPT in the group with normal findings on liver biopsy. The arrow indicates the time of liver biopsy. 


\section{References}

Bennike, T. (1960). Studier over Leveraffektionen ved Mononucleosis Infectiosa, pp. 150-158. Munkgaard, Copenhagen.

Committee on Threshold Limits (1959). Threshold limit values for 1959, adopted at the 21 st Annual Meeting of the American Conference of Governmental Industrial Hygienists. Arch. industr. Hlth, 20, 266-270.

Comstock, C. C., Lawson, L. H., Greene, E. A., and Oberst, F. W. (1954). Inhalation toxicity of hydrazine vapor. Arch. industr. Hyg., 10, 476-490.

Department of the Army Technical Bulletin (1957). Health Hazards from Propellant Fuels and Oxidizers, pp. 1-3.

Dill, D. B., and Jacobson, K. H. (1960). Toxicity of propellant fuels and oxidizers. U.S. armed Forces med. J., 11, 125-131.

Isselbacher, K. J., and Greenberger, N. J. (1964). Metabolic effects of alcohol on the liver. New Engl. J. Med., 270, 351-356 and 402-410.

Jacobson, K. H., Clem, J. H., Wheelwright, H. J., Rinehart, W. E., and Mayes, N. (1955). The acute toxicity of the vapors of some methylated hydrazine derivatives. Arch. industr. Hlth, 12, 609-616.

Kallai, L., Hahn, A., Röder, V., and Zupanić, V. (1964). Correlation between histological findings and serum transaminase values in chronic diseases of the liver. Acta med. scand., 175, 49-56.
Krop, S. (1954). Toxicology of hydrazine. Arch. industr. Hyg., 9, 199-204.

Laursen, T., and Hansen, P. From. (1958). A fluorimetric method for measuring the activity in serum of the enzyme glutamic pyruvic transaminase. Scand. J. clin. Lab. Invest., 10, 53-58.

, and Svendsen, B. Borup. (1959). Glutamic pyruvic transaminase in the serum during treatment with chlorpromazine. Dan. med. Bull., 6, 38-42.

Office of the Assistant Secretary of Defense, Research and Engineering (1958). Liquid Propellant. Chapt. 9.

Pare, C. M. B., and Sandler, M. (1959). Acute hepatic necrosis following iproniazid therapy. Lancet, 1, 282-284.

Reés, K. R., and Sinha, K. P. (1960). Blood enzymes in liver injury. J. Path. Bact., 80, 297-307.

Sherlock, S. (1963). Diseases of the Liver and Biliary System, 3rd ed., pp. 367-369. Blackwell, Oxford.

Shook, B. S., and Cowart, H. O. (1957). Health hazards associated with unsymmetrical dimethylhydrazine. Industr. Med. Surg., 26, 333-336.

Stumpe, A. R. (1958). Health hazards of new aircraft and rocket propellants. A review of the literature. J. Aviat. Med., 29, 650-659.

Vido, I., and Tomik, F. (1963). Morphologische Veränderungen der Leber und ihre Biochemischen Begleiterscheinungen im Serum während wiederholten unspezifischer Eingriffe bei Versuchstieren. Acta Hepato-Splenol. (Stuttg.), 10, 176-181.

Received for publication July 29, 1969. 